\title{
Health and Safety Consideration in the Procurement of Public Construction Projects in Ghana
}

\author{
Elijah Frimpong Boadu*, Riza Yosia Sunindijo (D) and Cynthia Changxin Wang (D) \\ School of Built Environment, The University of New South Wales, Sydney, NSW 2052, Australia; \\ r.sunindijo@unsw.edu.au (R.Y.S.); cynthia.wang@unsw.edu.au (C.C.W.) \\ * Correspondence: b.frimpong@unsw.edu.au
}

Citation: Boadu, E.F.; Sunindijo, R.Y.; Wang, C.C. Health and Safety Consideration in the Procurement of Public Construction Projects in Ghana. Buildings 2021, 11, 128. https:// doi.org/10.3390/buildings11030128

Academic Editor:

Derek Clements-Croome

Received: 7 February 2021

Accepted: 18 March 2021

Published: 20 March 2021

Publisher's Note: MDPI stays neutral with regard to jurisdictional claims in published maps and institutional affiliations.

Copyright: (c) 2021 by the authors. Licensee MDPI, Basel, Switzerland. This article is an open access article distributed under the terms and conditions of the Creative Commons Attribution (CC BY) license (https:// creativecommons.org/licenses/by/ $4.0 /)$.

\begin{abstract}
This study explored the extent to which health and safety (H\&S) are considered in the procurement of public sector projects in Ghana. This is based on the background that procurement decisions have implications for project $H \& S$ management. The enormous size of public procurement projects offers opportunities for public clients to influence the behaviour of the construction market including the promotion of H\&S through procurement. To date, no study has fully assessed the extent of H\&S considerations in procurement decisions for public sector construction projects in Ghana. To fill this gap, this research has provided an evidence-based assessment of H\&S considerations in the various stages of the procurement process for public sector projects in Ghana. Through a questionnaire survey, data were collected from construction industry professionals in Ghana. The data were subjected to statistical analysis to evaluate the extent of H\&S considerations. The findings suggest that $H \& S$ is given low priority in the procurement of public projects, because clear project objectives relating to $\mathrm{H} \& \mathrm{~S}$ are not set, and adequate consideration is not given to $\mathrm{H} \& \mathrm{~S}$ at the various procurement stages. Based on the findings, this research has made recommendations to promote $\mathrm{H} \& \mathrm{~S}$ in public procurement in Ghana.
\end{abstract}

Keywords: health and safety; procurement; public clients; consideration; construction industry

\section{Introduction}

Health and safety $(H \& S)$ issues are not confined to only the construction stage, but they influence all stages of a construction project, from the initiation to the operation stage. For instance, research has shown that many accidents on the construction site are caused by managerial decisions that are taken prior to the beginning of the work on the site $[1,2]$. Many studies have also emphasised that construction H\&S is not the responsibility of the contractors alone, but also that of the clients and designers [3,4]. Specifically, studies have disclosed that construction clients make important contributions to H\&S [4-7]. The client's involvement in H\&S management does not only reduce the number and severity of accidents but undoubtedly also reduces their total liability exposure.

The client has one of the biggest influences and contractual control over the way the project is run [8]. The decisions of the client determine the project team, when they are appointed, how they are appointed, their competences, and their assigned duties [8]. All these decisions relate to the procurement process and have implications for the management of H\&S on projects [9]. Deservedly, this has heightened the call for H\&S promotion in the procurement process, especially on public projects $[10,11]$ because it is acknowledged that public clients are the major procurers of construction projects and as such can exert influence on the market and drive the needed change within the industry. For instance, Ju and Rowlinson [12] observed that through the procurement process, public clients have influenced the implementation of H\&S measures in the Hong Kong construction industry.

Governments worldwide are increasingly recognising the immense power of public procurement to solve global societal challenges, improve productivity and boost innovation, 
while ensuring value for money. In Ghana, public procurement constitutes over $50 \%$ of government budgets, beside the cost of the public sector wage bill, and accounts for the largest share of government expenditure [13]. This shows a clear sign that public procurement has the potential to support broader policy objectives, including the promotion of H\&S in the construction industry.

The procurement process provides a structure and contractual relationship in which projects are executed. Lingard et al. [10] and Health and Safety Authority [14] opined that the procurement strategies adopted by clients have influence on the management of H\&S on projects. For instance, Rwelamila and Smallwood [15] expressed that the incorrect choice and use of procurement systems has contributed to the neglect of H\&S by project stakeholders. Therefore, the client's role should be emphasised in order to drive change from the top. Where there is awareness and commitment from the client, the H\&S messages can cascade down to the other parties involved in the project. Consequently, Health and Safety Executive (HSE) [16] suggested that more could be done to embed H\&S guidance and make it an integral part of procurement among public sector clients. It is based on these concepts that this research seeks to investigate the extent of H\&S considerations in the procurement process of public construction projects in Ghana.

To date, no study has fully assessed the extent of H\&S considerations in procurement decision making for public sector construction projects in Ghana. Therefore, this research aimed to provide an evidence-based assessment of how well H\&S issues are considered in the various stages of the procurement process for public sector projects in Ghana. More specifically, the study has the following objectives:

- To assess whether public sector clients set clear H\&S objectives and targets, and plan towards achieving them on their projects.

- To assess the extent to which H\&S issues are considered in decision-making in the various stages of the procurement process, namely, the tendering, tender evaluation and awarding, establishing conditions of contract, and contract administration and monitoring.

- To determine the relationship that exists between the H\&S considerations and activities within each procurement stage.

\section{Public Procurement and HES}

Generally, public procurement refers to the use of public or government funds to acquire works, goods and services needed for public projects and programmes. Amann et al. [17] defined it as the process by which central, regional, and local governments and other public authorities, bodies and agencies governed by public law and regulation, purchase and commission public works, goods, materials, and services. Public procurement represents a large proportion of public expenditure each year. The world's public procurement spending is estimated at 18.42 per cent [18]. The European Commission [19] estimated public procurement across the $27 \mathrm{EU}$ member countries to be 13.1 per cent of gross domestic product (GDP), excluding expenditure on utilities and defence. In the Organisation for Economic Cooperation and Development (OECD) countries, public procurement ranged between 19 to 45 per cent (averagely 29 per cent) of the total government spending [20] and it represented a size of approximately 12 per cent of GDP in the OECD countries [21]. According to the World Bank [22], it accounts for more than 15 per cent of GDP in African countries. In Ghana, public procurement contributes to about 17 per cent of GDP annually [13]. These show that public procurement has huge economic significance and has the potential to influence markets.

As a major procurer of works, goods and services, governments can leverage their large procuring capability to influence the behaviour of economic participants and outcomes [23]. Numerous studies have revealed that many countries (developed and developing) have used procurement as a tool to achieve several socioeconomic objectives [24]. A typical example is the Black Economic Empowerment strategy, introduced in postapartheid South Africa to prioritise public purchasing from black-owned businesses to 
compensate for the economic disadvantages they faced during the apartheid regime [25]. Furthermore, McCrudden [23] reported on the use of public procurement to promote equality on the basis of ethnicity and gender in Malaysia, Canada, South Africa and the European Community, and to promote human rights internationally by the International Labour Organisation. Similarly, in South Africa, the Construction Industry Development Board (CIDB) [26] recommended the use of public procurement to promote broad based black economic empowerment, gender or racial equality, work opportunities for small and medium enterprises (SMEs), etc. It further recommended that, where it is required to promote $\mathrm{H} \& \mathrm{~S}$ beyond the statutory performance, public procurement can be used to achieve that objective, thus becoming a useful tool for promoting H\&S in construction.

Nevertheless, promoting H\&S in the construction industry through procurement has not received much attention in developing countries such as Ghana. Wells and Hawkins [27] provided a briefing note to assist clients and financiers of construction projects, as well as procurement agencies to promote $\mathrm{H} \& \mathrm{~S}$ under the traditional procurement system in developing countries. This briefing note provided guidance on how to incorporate $\mathrm{H} \& \mathrm{~S}$ issues at the various stages of the procurement process including the pre-tender stage, selection of consultants, planning and design, pre-qualification of contractors, tender documentation, tender evaluation, contract documents, monitoring and reporting, and the post-project evaluation stages. Benviolent and Smallwood [28] assessed the implications of public sector procurement on the management of construction H\&S in Zimbabwe and found that $\mathrm{H} \& \mathrm{~S}$ issues are given very little priority compared to other criteria such as bid price, time, financial capability, experience, and quality. Donkor et al. [29] studied the role of stakeholders and the impact of the Public Procurement Act of 2003 (Act 663) on the way public sector clients incorporate $H \& S$ issues in construction procurement in Ghana. Their study found that the Act 663 does not address H\&S issues and also, H\&S is not considered in tender evaluation. These studies have created the awareness and made recommendations, but none has assessed to a comprehensive extent, the level of H\&S considerations in the procurement of public sector construction projects in Ghana. To fill the gap, this study sought to provide an evidence-based assessment of the extent to which $\mathrm{H} \& \mathrm{~S}$ issues are considered in the various stages of the procurement process for public sector projects in Ghana. Considering that the procurement decisions made by clients have huge implications for H\&S [9], it is important to assess the extent of H\&S considerations in these decisions. The knowledge of the full extent of $\mathrm{H} \& \mathrm{~S}$ consideration is a key step to developing strategies to promote $\mathrm{H} \& \mathrm{~S}$ within the procurement of public projects.

\section{Materials and Methods}

The research adopted the quantitative research approach to evaluate the extent of $\mathrm{H} \& \mathrm{~S}$ considerations in the procurement of public sector projects in Ghana. Generally, quantitative research allows for data to be collected and analysed through statistical procedures, with the aim to determine the truth or otherwise of theory or hypotheses [30]. The approach allows for a broader study and supports generalization of results. Thus, the quantitative approach was appropriate to explore the extent of $\mathrm{H} \& \mathrm{~S}$ consideration in the procurement of public projects in Ghana.

To be assured that the sampled participants can inform important facets and perspectives relating to the H\&S consideration in public procurement in Ghana, the sampling frame involved a population of construction industry professionals who have direct and indirect involvement in the procurement process for public projects. The participants were selected through a combination of non-probability sampling techniques such as convenience sampling and snowball sampling. Although non-probability sampling methods may be prone to selection bias and lack of representation of population, these participants were drawn from different type of organisations, namely, consultants, contractors, government institutions, trade unions/associations and suppliers. The participants were spread throughout Ghana, with different professional backgrounds and varied levels of construction industry experience. 
Survey questionnaires, both online and paper-based, were administered to participants. A total of 340 paper-based survey questionnaires were distributed and 176 were collected by researchers. However, out of the 176 collected surveys, 168 were deemed valid, and this represents a response rate of $49.4 \%$, with reference to the distributed questionnaires. Regarding the online survey, the link to the survey was distributed through emails, 'Whatsapp' and other social media platforms. Another 380 survey questionnaires were distributed via electronic or online platforms to construction industry professionals. Out of this, 119 valid responses were received, resulting in a response rate of $31.3 \%$. Thus, in total, approximately 720 questionnaires were distributed to the sampled population, and a total of 287 valid responses were received. This represents a relatively high response rate of almost $40 \%$, considering that the response rate in construction management research is widely recognised as being particularly low [31]. Although a higher response rate is preferable in a survey, it does not necessarily lead to more accurate results [32].

The questionnaires were designed to investigate the extent of H\&S considerations in the various stages of the procurement process for public sector projects in Ghana and the H\&S performance on those projects. The Likert scale, ranging from 1 to 5 , where $1=$ strongly disagree, 2 = disagree, $3=$ neutral, $4=$ agree and $5=$ strongly agree, was used to guide respondents. The survey was accompanied by a cover letter and a participant information statement and consent form (PISCF). Before responding to the survey, participants were required to read the PISCF to acquaint themselves with the objectives of the research and the risks associated with participation before consenting to participate in the study. To avoid biases associated with the data collection and to assure participants of their anonymity, the survey avoided the collection of personally identifying information, such as names, addresses, phone numbers, etc. Further, responses were not sought through a face-to-face or over the phone approach.

In this research, the procurement stages (see Figure 1) have been adapted from Akintoye and Main [33] and the International Organisation for Standardisation [34]. These stages are the objectives and planning, tendering, tender evaluation and contract award, conditions of contract, and contract administration and monitoring stages.

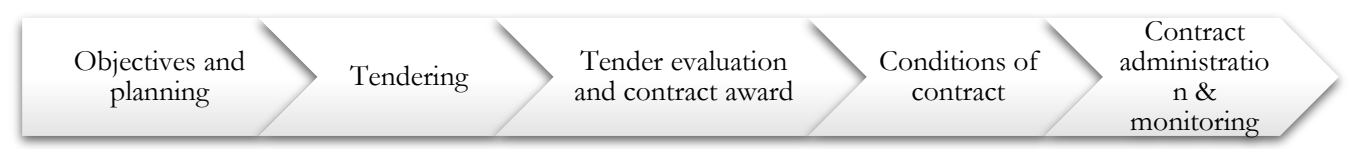

Figure 1. Stages of construction procurement (adapted from Akintoye and Main [33] and the International Organisation for Standardisation [34]).

The early stage of the procurement process involves identification of requirements or items to be procured, which is determined by the clients in line with their objectives [35]. It is essentially the planning and scoping phase. During this phase, specifications and contract packages are determined. The specifications communicate the project objectives and outline all the necessary requirements in order to complete the project [36]. This phase sets the whole procurement process in motion and therefore lapses may have serious implication for the outcomes of the whole process [37]. The second phase is the tendering or sourcing phase, which determines the appropriate procurement strategy. Sourcing can be competitive or sole-sourced. Generally, the method of sourcing often depends on the client's objectives as well as the size and complexity of the project, risks, sources of funding, and the urgency of the project, among others. The most common forms of sourcing in construction are the invitations to tender and requests for proposals. Once tenders are received in response to the invitation, clients evaluate them and select the contractor whose offer provides the "best value". The client then awards the project to the contractor through a form of contract. The contract establishes a legal relationship, which shapes the behaviour of the client and contractor throughout the contract period. The contract outlines the method of executing the project and the payment mechanism; it is the legal document to which any disagreements, conflicts and disputes are referred for settlement. The final 
phase involves managing and supervising the awarded contract to ensure that all parties (client and contractor) perform their contractual duties.

Respondents were asked to rate the extent to which H\&S is considered in the various procurement stages of public projects. The questionnaires were based on the activities which are carried out, as well as decisions taken in the various stages. Some of the questionnaire items were adapted from HSE [16] and Worksafe Victoria [38], while others were newly developed. Steps were taken to ensure that the designed questionnaire was 'respondent-friendly'. All the questions were positively worded to prevent, as far as possible, any confusion.

\section{Results and Discussion}

This section presents the analyses and discussions of the data, including the demographic profiles of respondents and their perspectives on the extent of H\&S considerations in the various stages of procurement. It further presents the analysis of variances (ANOVA) tests and the correlation between the H\&S items within the various stages. To verify the internal consistency reliability of the items in each procurement stage, the Cronbach's alpha test was conducted. The internal consistency was used to assess whether the responses across the items on each procurement stage were consistent. Traditionally, it offers the appropriate test to evaluate reliability across items, because it estimates the reliability based on the correlations between the items [39]. Internal consistency that ranges between 0.50 to 0.70 is acceptable, $0.70-0.90$ represents high internal consistency, and 0.90 and above represents excellent reliability [40].

\subsection{Demographic Profile of Respondents}

The first section of the survey questionnaire was used to collect the background information of respondents. Various construction industry professionals have participated in this research ranging from project managers, H\&S personnel, quantity surveyors, architects, engineers, site managers, construction managers, and procurement personnel, among others. The profile of the respondents, including their age, years of work experience in the construction industry, number of public projects undertaken, and the nature of their organisations, is presented in Table 1.

Table 1. Demographic profile of respondents.

\begin{tabular}{|c|c|c|c|c|}
\hline S/n & Parameter & Category & Frequency & Per cent $(\%)$ \\
\hline \multirow{9}{*}{1.} & \multirow{9}{*}{ Age (in years) } & $18-25$ & 15 & 5.23 \\
\hline & & $26-30$ & 47 & 16.38 \\
\hline & & $31-35$ & 52 & 18.12 \\
\hline & & $36-40$ & 63 & 21.95 \\
\hline & & $41-45$ & 42 & 14.63 \\
\hline & & $46-50$ & 36 & 12.54 \\
\hline & & $51-55$ & 23 & 8.01 \\
\hline & & $56-60$ & 7 & 2.44 \\
\hline & & Above 60 & 2 & 0.70 \\
\hline \multirow{5}{*}{2.} & \multirow{5}{*}{$\begin{array}{l}\text { Years of work } \\
\text { experience }\end{array}$} & $1-5$ & 65 & 22.65 \\
\hline & & $6-10$ & 66 & 23.00 \\
\hline & & $11-15$ & 67 & 23.34 \\
\hline & & $16-20$ & 57 & 19.86 \\
\hline & & Above 20 years & 32 & 11.15 \\
\hline \multirow{5}{*}{3.} & \multirow{5}{*}{$\begin{array}{c}\text { Number of public } \\
\text { project(s) undertaken }\end{array}$} & $1-5$ & 65 & 22.65 \\
\hline & & $6-10$ & 60 & 20.91 \\
\hline & & 11-15 & 50 & 17.42 \\
\hline & & $16-20$ & 54 & 18.82 \\
\hline & & Above 20 & 58 & 20.21 \\
\hline \multirow{5}{*}{4.} & \multirow{5}{*}{ Nature of organisation } & Consultant & 88 & 30.66 \\
\hline & & Contractor & 87 & 30.31 \\
\hline & & Government & 104 & 36.24 \\
\hline & & Supplier & 5 & 1.74 \\
\hline & & Industry/Trade association & 3 & 1.05 \\
\hline
\end{tabular}




\subsection{HES Considerations in Public Procurement}

On a Likert scale of one (strongly disagree) to five (strongly agree), the respondents rated the extent of their agreement to some statements relating to H\&S considerations in the various stages of the procurement process for public projects in Ghana. The choice of one or two on the Likert scale represents a significant extent of disagreement, and four or five shows significant agreement with the level of $\mathrm{H} \& \mathrm{~S}$ consideration relating to the specific statement [41]. The following sections discuss the responses received. For the purposes of showing the differences in views across the various types of organisations, the mean responses for consultants $(n=88)$, contractors $(n=87)$ and government institutions $(n=104)$ are presented. The mean responses from suppliers $(n=5)$ and industry/trade associations $(n=3)$ are not presented separately because few responses were received from these groups; however, responses from these groups are incorporated into the overall mean responses.

\subsubsection{Planning Stage}

Setting H\&S performance objectives or targets for projects is viewed as one of the key and primary considerations towards achieving better H\&S performance on projects [11,27]. Setting clear H\&S objectives and the subsequent actions taken during the initial planning stages of projects provide an important blueprint for the implementation of H\&S considerations and measures, as well as proper allocation of the organisation's resources towards achieving the desired H\&S outcomes. Thus, establishing the appropriate H\&S objectives and targets for projects and other related actions during the planning stage of procurement can have a significant impact on the H\&S management within the entire project.

Table 2 presents the extent to which public clients set H\&S objectives or targets for their projects, as well as how H\&S issues are considered in the planning stage of the procurement process. Generally, the results show that public clients do not usually set clear and explicit H\&S objectives or targets for their projects. Thus, $H \& S$ issues are given little or no priority in the procurement of public projects in Ghana. In addition, the respondents believe that adequate consideration is not given to $H \& S$ issues at the planning stage of the procurement process. This is evident in the low mean responses obtained in relation to the H\&S considerations in the planning stage activities.

Clearly, unlike project objectives such as cost, time and quality, public clients do not usually set and prioritise H\&S objectives or targets for their construction projects. This finding corroborates the research findings of Alkilani et al. [42], which revealed that H\&S objectives are normally given a low priority in developing countries. Evidence suggests that $\mathrm{H} \& \mathrm{~S}$ is poorly considered when choosing the procurement method for projects and the use of a client risk register is not widespread [16]. Considering that the choice of the procurement method has implications for the management of H\&S on projects [15,43], failure to consider H\&S in an adequate manner may have dire consequences for $H \& S$ implementation on the project.

The planning stage is a vital phase of the project procurement process as it identifies and expresses the client's project needs. The project requirements are developed and communicated at this stage, and an assessment of available options are carried out to select an approach that is appropriate for the project. Mostly, these decisions are taken after considering several factors in relation to the project priority objective [44]. This emphasises the point that if H\&S objectives are not expressly set and prioritised at the planning stage of the project, subsequent decisions within the planning stage will fail to adequately consider H\&S issues. Therefore, considering that the client's project objectives heavily dictate subsequent procurement decisions, it is important that H\&S issues are thoroughly highlighted earlier in the project. 
Table 2. Health and safety (H\&S) considerations at the planning stage of public projects.

\begin{tabular}{|c|c|c|c|c|c|}
\hline$S / n$ & Considerations & Consultants & Contractors & Gov't Inst. & Overall \\
\hline OPL1 & $\begin{array}{l}\text { Public sector clients usually set H\&S objectives and targets for } \\
\text { their projects. }\end{array}$ & 2.75 & 2.70 & 2.91 & 2.81 \\
\hline OPL2 & $\begin{array}{l}\text { H\&S objective/target is equally important to public sector clients } \\
\text { just like other project objectives such as cost, time, and quality. }\end{array}$ & 2.86 & 2.70 & 2.93 & 2.84 \\
\hline OPL3 & $\begin{array}{l}\text { H\&S targets are emphasised and communicated to the project } \\
\text { team throughout the procurement stage of public projects. }\end{array}$ & 2.67 & 2.63 & 2.80 & 2.71 \\
\hline OPL4 & $\begin{array}{l}\text { Public clients ensure that their project designers have the capacity } \\
\text { and quality to incorporate safety considerations into designs } \\
\text { before appointing them. }\end{array}$ & 3.19 & 2.89 & 3.19 & 3.10 \\
\hline OPL5 & $\begin{array}{l}\mathrm{H} \& \mathrm{~S} \text { conditions are usually explicitly specified by public clients } \\
\text { in the terms of contract with designers. }\end{array}$ & 2.99 & 2.86 & 3.03 & 2.96 \\
\hline OPL6 & $\begin{array}{l}\text { Public clients develop a client risk register including H\&S risks } \\
\text { for their project. }\end{array}$ & 2.26 & 2.34 & 2.56 & 2.41 \\
\hline OPL7 & $\begin{array}{l}\text { When choosing between design options for public projects, H\&S } \\
\text { issues are highly considered. }\end{array}$ & 2.66 & 2.68 & 2.71 & 2.70 \\
\hline OPL8 & $\begin{array}{l}\text { Public clients usually make allocations within their project } \\
\text { budgets to manage H\&S issues. }\end{array}$ & 2.86 & 2.69 & 2.95 & 2.85 \\
\hline OPL9 & $\begin{array}{l}\text { Public clients set the standard for H\&S competence and capacity } \\
\text { that a contractor needs to have in order to work on their projects. }\end{array}$ & 2.74 & 2.67 & 2.85 & 2.78 \\
\hline OPL10 & $\begin{array}{l}\text { Adequate consideration is usually given to H\&S issues when } \\
\text { choosing between the procurement methods for public projects. }\end{array}$ & 2.51 & 2.69 & 2.53 & 2.58 \\
\hline
\end{tabular}

Cronbach's alpha $=0.930$ (internally consistent)

\subsubsection{ANOVA of Objectives and Planning Stage Items}

In order to verify whether the views of the respondents were influenced by the nature of their organisations, ANOVA was performed on the responses from different organisations, namely, consultants, contractors and government institutions; the results are presented in Table 3. Prior to conducting the ANOVA test, the data was checked for normality and homogeneity of variances (see Table 3). Skewness and kurtosis indices were used to identify the normality of the data. With skewness values ranging between -0.348 to 0.515 and kurtosis values between -1146 to -0.610 , the assumption of normality was determined to be fulfilled. According to Byrne [45], if skewness values range between -2 to +2 and the kurtosis values fall between -7 to +7 , then assumption of normality is fulfilled. The assumption of homogeneity of variances was tested based on Lavene's $F$ test, and the results showed that one variable (see OPL2) violated the homogeneity of variance assumption needed for a regular ANOVA test. Therefore, the Welch ANOVA test was performed instead of the regular one-way ANOVA test.

Table 3. One-way analysis of variances (ANOVA) for H\&S considerations at the planning stage.

\begin{tabular}{ccccccc}
\hline \multirow{2}{*}{ S/n } & \multicolumn{2}{c}{ Test for Normality } & \multicolumn{2}{c}{ Homogeneity Test } & \multicolumn{2}{c}{ Welch ANOVA } \\
\cline { 2 - 6 } & Kurtosis & Skewness & Levene & Sig. & Statistic & Sig. \\
\hline OPL1 & -1.146 & 0.246 & 1.588 & 0.206 & 1.021 & 0.362 \\
OPL2 & -1.147 & 0.380 & 4.686 & 0.010 & 0.983 & 0.376 \\
OPL3 & -0.669 & 0.503 & 0.509 & 0.602 & 0.613 & 0.543 \\
OPL4 & -0.820 & -0.348 & 0.319 & 0.727 & 2.521 & 0.083 \\
OPL5 & -0.853 & 0.020 & 0.635 & 0.531 & 0.644 & 0.527 \\
OPL6 & -0.745 & 0.515 & 0.174 & 0.840 & 1.859 & 0.159 \\
OPL7 & -0.887 & 0.479 & 0.189 & 0.828 & 0.054 & 0.948 \\
OPL8 & -0.998 & 0.063 & 1.110 & 0.331 & 1.346 & 0.263 \\
OPL9 & -0.899 & 0.312 & 1.128 & 0.325 & 0.739 & 0.479 \\
OPL10 & -0.610 & 0.495 & 0.038 & 0.963 & 0.762 & 0.468 \\
\hline
\end{tabular}


From Table 3, the results of the Welch ANOVA test reveal that there were no statistically significant differences in the mean responses between the three organisations. This result shows that the views of the respondents regarding H\&S objectives and considerations at the planning stage have not been influenced significantly by the nature of their organisations.

\subsubsection{Relationships between the Planning Stage Items}

The relationship between the years of work experience and the planning stage H\&S considerations has been analysed using Spearman's correlation and the results presented in Table 4. Experience has been found to be a key determinant of H\&S perceptions [46]. Therefore, correlating the years of work experience with the planning stage H\&S considerations provides an idea about how the beliefs and perspectives of the industry professionals have been shaped by their level of professional experience within the industry.

Table 4. Correlation coefficient between the H\&S considerations at the planning stage.

\begin{tabular}{|c|c|c|c|c|c|c|c|c|c|c|c|}
\hline Spearman's Rho & Experience & OPL1 & OPL2 & OPL3 & OPL4 & OPL5 & OPL6 & OPL7 & OPL8 & OPL9 & OPL10 \\
\hline Experience & 1 & & & & & & & & & & \\
\hline OPL1 & $-0.331 * *$ & 1 & & & & & & & & & \\
\hline OPL2 & $-0.352 * *$ & $0.720 * *$ & 1 & & & & & & & & \\
\hline OPL3 & $-0.351 * *$ & $0.685^{* *}$ & $0.682 * *$ & 1 & & & & & & & \\
\hline OPL4 & -0.018 & $0.389 * *$ & $0.358 * *$ & $0.439 * *$ & 1 & & & & & & \\
\hline OPL5 & $-0.180 * *$ & $0.431 * *$ & $0.520 * *$ & $0.526 * *$ & $0.581 * *$ & 1 & & & & & \\
\hline OPL6 & $-0.386^{* *}$ & $0.654 * *$ & $0.633^{* *}$ & $0.679 * *$ & $0.355^{* *}$ & $0.541 * *$ & 1 & & & & \\
\hline OPL7 & $-0.343 * *$ & $0.552 * *$ & $0.610 * *$ & $0.682 * *$ & $0.447 * *$ & $0.565^{* *}$ & $0.646 * *$ & 1 & & & \\
\hline OPL8 & $-0.214^{* *}$ & $0.605^{* *}$ & $0.509 * *$ & $0.573 * *$ & $0.488^{* *}$ & $0.483^{* *}$ & $0.550 * *$ & $0.626^{* *}$ & 1 & & \\
\hline OPL9 & $-0.317^{* *}$ & 0.634 ** & $0.604 * *$ & $0.644 * *$ & $0.449 * *$ & $0.546 * *$ & $0.629 * *$ & $0.639 * *$ & $0.676^{* *}$ & 1 & \\
\hline OPL10 & $-0.344^{* *}$ & $0.541 * *$ & $0.573 * *$ & $0.649 * *$ & $0.382 * *$ & $0.581 * *$ & $0.658 * *$ & $0.699 * *$ & $0.521^{* *}$ & $0.636^{* *}$ & 1 \\
\hline
\end{tabular}

** Correlation is significant at the 0.01 level (2-tailed).

From Table 4, the results show a significant negative relationship between experience and all the objectives and planning stageH\&S considerations, except for OPL4. This relationship reveals that the more experienced the respondents are, the more likely they are to disagree that public clients set H\&S objectives and adequately consider H\&S issues at the planning stage of the procurement process. Considering that experience is an important source of H\&S information [47], this relationship reveals a deep-seated belief that public clients adopt practices and norms that do not promote and prioritise H\&S issues at the planning stages of their construction projects.

Furthermore, the results show a significant positive relationship among the various $H \& S$ considerations at the planning stage. For instance, there is a strong significant positive relationship between OPL1 and all the other H\&S items. Clients who set clear H\&S objectives or targets for their projects may likely prioritise H\&S issues and subsequently carefully incorporate these H\&S issues into all the procurement decisions [43]. This relationship emphasises the idea that setting clear and measurable H\&S objectives ensures that appropriate procedures, activities, and adequate resources are allocated to achieve them [48,49]. Project objectives are key determinants of procurement strategy [44] and it is critical that H\&S objectives are adequately integrated into the procurement process, rather than being considered an add-on, which is the current practice.

What is also shown in this relationship is that when a client adequately checks and appoints designers who are H\&S competent, the client is also likely to express clear H\&S provisions in the designer's conditions of contract, consider H\&S in the choice of design options for the project, adequately develop a risk register and ultimately, make allocations in the project budget to manage H\&S. Lingard et al. [50] asserted that pushing some of the responsibilities for H\&S up the supply chain to involve designers and professional contributors during the planning and design phase effectively identifies and minimises risks, triggers allocation of resources and generally improves H\&S systems. 


\subsubsection{Tendering Stage}

The tendering stage of the procurement process provides opportunity for clients to emphasise the need to promote H\&S on their projects. Clients who consider H\&S issues in tendering may establish appropriate $\mathrm{H} \& \mathrm{~S}$ requirements for prospective contractors and clearly communicate these requirements in the tender documentation. This process will enable prospective contractors to comprehend their H\&S obligations well in advance and allow clients to eliminate unscrupulous contractors.

Table 5 presents the views of respondents on the extent to which public clients consider $\mathrm{H} \& \mathrm{~S}$ issues at the tendering and prequalification stages of their projects. The results largely indicate that public clients do not significantly consider H\&S issues at the tendering stage. Evidently, respondents believe that public clients do not consider H\&S in the choice of their tendering methods, inadequately specify and communicate H\&S issues in tender documentations, insufficiently assign weighting to $H \& S$, and do not usually consider H\&S as criteria for prequalification. The HSE [16] found that most clients adopt procurement and tendering methods that are pre-determined by their parent body, and therefore H\&S matters are not considered in the choice of these methods. This reason and others, such as certain provisions in the governing Public Procurement Act of 2003 (Act 663) and the Public Procurement (Amendment) Act of 2016 (Act 914), may account for the situation where $H \& S$ issues are not adequately considered in the choice of tendering methods. For instance, Act 663 clearly states that public clients shall procure works through competitive tendering, except in exceptional circumstances (which would require express approval from the Public Procurement Authority). Furthermore, it is advocated that H\&S issues must be given appropriate weighting relative to the degree of risks identified during the planning stage [38]. However, considering that clients do not clearly develop a risk register to establish the level of $H \& S$ risks, the requirement to give appropriate weighting to $H \& S$ is farfetched.

Table 5. H\&S considerations at the tendering stage of public projects.

\begin{tabular}{|c|c|c|c|c|c|}
\hline$S / n$ & Consideration & Consultants & Contractors & Gov't Inst. & Overall \\
\hline TEN1 & $\begin{array}{l}\text { H\&S is an important consideration in choosing which } \\
\text { tendering method to adopt for public projects. }\end{array}$ & 2.66 & 2.57 & 2.64 & 2.65 \\
\hline TEN2 & $\begin{array}{l}\text { Public clients usually specify clearly how H\&S issues } \\
\text { must be addressed in tenders by prospective contractors. }\end{array}$ & 2.80 & 2.64 & 2.95 & 2.81 \\
\hline TEN3 & $\begin{array}{l}\text { Public clients usually include applicable H\&S regulations } \\
\text { in their tender documents to emphasise the requirement } \\
\text { for H\&S to be addressed by contractors. }\end{array}$ & 2.69 & 2.62 & 2.77 & 2.71 \\
\hline TEN4 & $\begin{array}{l}\text { H\&S matters are assigned adequate weight in the tender } \\
\text { selection criteria for public projects. }\end{array}$ & 2.33 & 2.26 & 2.33 & 2.32 \\
\hline TEN5 & $\begin{array}{l}\text { H\&S consideration is among the key criteria used for } \\
\text { shortlisting contractors for public projects. }\end{array}$ & 2.39 & 2.44 & 2.43 & 2.43 \\
\hline
\end{tabular}

\subsubsection{ANOVA of the Tendering Stage Items}

ANOVA was used to verify whether there were significant differences in the mean responses among the various organisations. The assumption of normality and homogeneity of the data was tested before performing the ANOVA. The results (see Table 6) show the assumption of normality was fulfilled but the assumption of homogeneity of variance was violated (see TEN4). Consequently, the Welch ANOVA test was performed. 
Table 6. One-way ANOVA for H\&S considerations at the tendering stage.

\begin{tabular}{ccccccc}
\hline & \multicolumn{2}{c}{ Test for Normality } & \multicolumn{2}{c}{ Homogeneity Test } & \multicolumn{2}{c}{ Welch ANOVA } \\
\cline { 2 - 6 } S/n & Kurtosis & Skewness & Levene & Sig. & Statistic & Sig. \\
\hline TEN1 & -0.331 & 0.605 & 0.932 & 0.395 & 0.169 & 0.845 \\
TEN2 & -0.849 & 0.206 & 0.393 & 0.675 & 2.073 & 0.129 \\
TEN3 & -0.939 & 0.331 & 1.418 & 0.244 & 0.457 & 0.634 \\
TEN4 & -0.064 & 0.725 & 3.717 & 0.026 & 0.113 & 0.893 \\
TEN5 & -0.249 & 0.652 & 1.871 & 0.156 & 0.064 & 0.938 \\
\hline
\end{tabular}

The results from Table 6 show that the mean responses from the three organisations were not significantly different from each other. Essentially, the results suggest that the respondents' views in relation to $\mathrm{H} \& \mathrm{~S}$ considerations at the tendering stage of the procurement process have not been significantly influenced by the nature of their organisations.

\subsubsection{Relationships between the Tendering Stage Items}

Table 7 presents the correlation between respondents' experiences and the various $\mathrm{H} \& \mathrm{~S}$ considerations at the tendering stage. The results show significant negative relationships between experience and all the tendering stage H\&S considerations. This demonstrates that the more experienced the respondents are, the more likely they are to disagree that public clients consider H\&S issues in the tendering stage. There are strong significant positive relationships among the tendering stage H\&S items. Clients who thoroughly consider H\&S issues in the selection of the tendering method are likely to provide adequate H\&S information in tender documents and assign adequate weighting to H\&S criteria. The relationships are evident given that when $\mathrm{H} \& \mathrm{~S}$ issues are clearly expressed in tender, it provides contractors with the required $H \& S$ information at the tendering stage and communicates the client's commitment to consider H\&S issues as one of the criteria for contractor selection $[27,51]$.

Table 7. Correlation coefficient between the H\&S considerations at the tendering stage.

\begin{tabular}{ccccccc}
\hline Spearman's Rho & Experience & TEN1 & TEN2 & TEN3 & TEN4 & TEN5 \\
\hline Experience & 1 & & & & & \\
TEN1 & $-0.287^{* *}$ & 1 & & & & \\
TEN2 & $-0.191^{* *}$ & $0.443^{* *}$ & 1 & & & \\
TEN3 & $-0.385^{* *}$ & $0.498^{* *}$ & $0.700^{* *}$ & 1 & & \\
TEN4 & $-0.402^{* *}$ & $0.563^{* *}$ & $0.580^{* *}$ & $0.639^{* *}$ & 1 & \\
TEN5 & $-0.324^{* *}$ & $0.495^{* *}$ & $0.403^{* *}$ & $0.448^{* *}$ & $0.566^{* *}$ & 1 \\
\hline
\end{tabular}

** Correlation is significant at the 0.01 level (2-tailed).

\subsubsection{Tender Evaluation Stage}

When tenders for a project are received, the client and their advisors assess and evaluate the tenders to ensure that potential contractors have fully complied with the requirements in the tender documents including those relating to H\&S. The assessment and evaluation ensure that potential contractors are competent to carry out the work. Therefore, the processes and criteria used in evaluating and selecting contractors are critical for ensuring that H\&S responsibility is taken seriously.

In Table 8, the views of respondents on the extent to which H\&S issues are considered in tender evaluation for public projects are presented. The results show that H\&S issues are accorded low priority and, as such, not given adequate consideration at the tender evaluation stage. Clearly, the respondents believe that public clients do not include comprehensive $\mathrm{H} \& \mathrm{~S}$ related items in their project estimates (bill of quantities, $\mathrm{BOQ}$ ) in order to compare and evaluate tenders. This is in line with a study by the Cooperative Research Centre for Construction Innovation ( CRC) [52] which found that many project estimates fail to adequately factor $H \& S$ costs. It is believed that $H \& S$ expert advice is not sought in the 
evaluation of tenders and even H\&S submissions by contractors are not duly investigated. Consequently, it has become apparent that tenders that do not make adequate provisions for H\&S stand a chance of winning the contract [53] because H\&S are not considered mandatory criteria or one of the key criteria for winning tenders. The findings reinforce the arguments of Harding [54] and Okorie et al. [55] that H\&S issues are not a priority when clients are choosing contractors and, as such, they are mostly overlooked.

Table 8. H\&S considerations at tender evaluation.

\begin{tabular}{|c|c|c|c|c|c|}
\hline$S / n$ & Consideration & Consultants & Contractors & Gov't Inst. & Overall \\
\hline TEV1 & $\begin{array}{l}\text { Public clients include comprehensive H\&S-related costs in } \\
\text { their project cost estimates to compare and evaluate tenderers. }\end{array}$ & 2.52 & 2.60 & 2.62 & 2.60 \\
\hline TEV2 & $\begin{array}{l}\text { H\&S experts are included or consulted in evaluating H\&S } \\
\text { aspects of tenders for public projects. }\end{array}$ & 2.33 & 2.38 & 2.49 & 2.44 \\
\hline TEV3 & $\begin{array}{l}\text { Due diligence is mostly done on each tenderer's H\&S } \\
\text { submissions for public projects. }\end{array}$ & 2.42 & 2.22 & 2.55 & 2.43 \\
\hline TEV4 & $\begin{array}{l}\text { Tenders that do not meet H\&S requirements are not evaluated } \\
\text { for public project contracts. }\end{array}$ & 2.47 & 2.29 & 2.52 & 2.45 \\
\hline TEV5 & $\begin{array}{l}\text { H\&S submissions can make the difference between a tenderer } \\
\text { getting a contract for a public project or not. }\end{array}$ & 2.30 & 2.20 & 2.37 & 2.31 \\
\hline
\end{tabular}

\subsubsection{ANOVA and Post Hoc Test of the Tender Evaluation Stage Items}

Table 9 presents the ANOVA test to check for any significant differences in the mean responses between the organisations. One factor (see TEV3) violated the assumption of homogeneity of variance needed for a regular ANOVA. From Table 9, the results of the Welch ANOVA test indicated that there was a significant difference in the mean responses for TEV3. Subsequently, the source and nature of the differences in the statistically significant ANOVA were determined by performing the Games-Howell's post-hoc multiple comparison test and the results are presented in Table 9.

Table 9. One-way ANOVA for H\&S considerations in tender evaluation.

\begin{tabular}{|c|c|c|c|c|c|c|}
\hline \multirow[b]{2}{*}{$\mathrm{S} / \mathrm{n}$} & \multicolumn{2}{|c|}{ Test for Normality } & \multicolumn{2}{|c|}{ Homogeneity Test } & \multicolumn{2}{|c|}{ Welch ANOVA } \\
\hline & Kurtosis & Skewness & Levene & Sig. & Statistic & Sig. \\
\hline TEV1 & -0.559 & 0.478 & 0.860 & 0.424 & 0.213 & 0.808 \\
\hline TEV2 & -0.182 & 0.729 & 1.407 & 0.247 & 0.596 & 0.552 \\
\hline TEV3 & -0.211 & 0.620 & 5.287 & 0.006 & 2.963 & 0.050 \\
\hline TEV4 & -0.054 & 0.719 & 2.653 & 0.072 & 1.430 & 0.242 \\
\hline \multirow[t]{2}{*}{ TEV5 } & -0.737 & 0.574 & 1.692 & 0.186 & 0.505 & 0.605 \\
\hline & \multicolumn{3}{|c|}{ Post hoc test (Games-Howell) } & & Mean Diff. & Sig. \\
\hline TEV3 & \multicolumn{3}{|c|}{$\begin{array}{l}\text { Due diligence is mostly done on each tenderer's H\&S } \\
\text { submissions for public projects. }\end{array}$} & $\begin{array}{l}\text { Consultants/Contractors } \\
\text { Consultants/Gov't Inst. } \\
\text { Contractors/Gov't Inst. }\end{array}$ & $\begin{array}{c}0.202 \\
-0.128 \\
-0.330 *\end{array}$ & $\begin{array}{l}0.089 \\
0.912 \\
0.044\end{array}$ \\
\hline
\end{tabular}

\footnotetext{
* The mean difference is significant at the 0.05 level.
}

The post-hoc comparison on TEV3 showed that the difference between the mean responses from contractors and government institutions was statistically significant (MD $=-0.330$, $p=0.044)$. Essentially, the results showed that contractors and government institutions differed significantly in their beliefs on whether due diligence is adequately carried out on contractors' H\&S submissions during tender evaluation for public projects. While government institutions felt that they did due diligence to an extent, contractors felt that they had not done it adequately. This show that the contractors do not trust the clients when it comes to 
conducting due diligence. The views of the contractors may have been shaped based on the premise that corruption and unethical practices prevail among public officials, construction professionals and contractors during the tender evaluation stage of public projects [56,57].

\subsubsection{Relationships between the Tender Evaluation Items}

Experience and the various tender evaluation stage H\&S items have been correlated and the results presented in Table 10. The results show a significant negative relationship between experience and the various tender evaluation items. There is a strong positive correlation among the different tender evaluation items. Largely, these relationships indicate that an adequate consideration of one item may lead to a significant consideration of another. During tender evaluation, clients assess tenderers' submissions against the documented requirements. Thus, a project estimate that makes provision for comprehensive $H \& S$ related items enables clients to appropriately compare and evaluate tenderers' H\&S submissions $[38,58]$. Having made such provisions, the client may likely seek expert advice to be assured that $H \& S$ issues have been adequately addressed in the tender submission in line with the requirements [58]. Due diligence may be carried out by the experts to verify the information provided by tenderers. Consequently, any tender that does not meet the mandatory criteria, such as the H\&S requirements, or provides fake submissions may be rejected. Additionally, having assessed the tenders against the mandatory H\&S criteria, as part of a screening process, clients who adequately consider the above H\&S issues are likely to also consider H\&S as one of the key evaluation criteria for selecting a contractor.

Table 10. Correlation coefficient between the H\&S considerations at the tender evaluation.

\begin{tabular}{ccccccc}
\hline Spearman's rho & Experience & TEV1 & TEV2 & TEV3 & TEV4 & TEV5 \\
\hline Experience & 1 & & & & & \\
TEV1 & $-0.309^{* *}$ & 1 & & & & \\
TEV2 & $-0.364^{* *}$ & $0.670^{* *}$ & 1 & & & \\
TEV3 & $-0.231^{* *}$ & $0.575^{* *}$ & $0.667^{* *}$ & 1 & & \\
TEV4 & $-0.398^{* *}$ & $0.640^{* *}$ & $0.656^{* *}$ & $0.632^{* *}$ & 1 & \\
TEV5 & $-0.400^{* *}$ & $0.609^{* *}$ & $0.626^{* *}$ & $0.578^{* *}$ & $0.701^{* *}$ & 1 \\
\hline **
\end{tabular}

** Correlation is significant at the 0.01 level (2-tailed).

\subsubsection{Conditions of Contract}

Best practice in project H\&S management requires contract conditions to clearly express the contractual obligations relating to H\&S for all contractors and subcontractors who may be involved in the project. Generally, the conditions of contract provide the terms of agreement and set the rights and obligations of all the contracting parties. Therefore, the conditions of contract document provides a good opportunity for clients to clearly demonstrate their commitment to achieving better H\&S performance on their projects.

Table 11 presents the views of respondents on the extent to which H\&S issues are considered in contract conditions for public projects. The results show that H\&S issues are not sufficiently provided for in the conditions of contract documents that govern public projects in Ghana. This is consistent with the findings of previous studies which revealed that many contract conditions for construction projects fail to adequately make provisions for H\&S management [27,52]. While standard forms of contracts are usually adopted for managing projects, respondents believed that these standard forms of contract do not address H\&S management issues in an adequate manner. Sharkey et al. [59] highlighted this in a study of the standard forms of contract used in the Australian construction industry, where it was revealed that up to $69 \%$ of the time, the H\&S clauses in the standard forms of contract are amended to deal with work H\&S requirements; this essentially indicates that the H\&S provisions in the standard forms are inadequate and/or imprecise. 
Table 11. H\&S considerations in conditions of contract.

\begin{tabular}{|c|c|c|c|c|c|}
\hline $\mathrm{S} / \mathrm{n}$ & Consideration & Consultants & Contractors & Gov't Inst. & Overall \\
\hline COC1 & $\begin{array}{l}\text { H\&S provisions in the standard forms of contract are mostly } \\
\text { adequate for addressing the requirements of H\&S legislations. }\end{array}$ & 2.89 & 2.74 & 2.84 & 2.85 \\
\hline COC2 & $\begin{array}{l}\text { Public clients usually include additional project specific } \\
\text { conditions of contract to manage project H\&S risks. }\end{array}$ & 2.70 & 2.64 & 2.73 & 2.72 \\
\hline COC3 & $\begin{array}{l}\text { Contract conditions for public projects prescribe penalty } \\
\text { and/or incentive clauses for poor H\&S performance and } \\
\text { accident-free project delivery, respectively. }\end{array}$ & 2.51 & 2.47 & 2.53 & 2.52 \\
\hline $\mathrm{COC} 4$ & $\begin{array}{l}\text { H\&S issues are prominently considered and discussed in } \\
\text { contract negotiations with contractors for public projects. }\end{array}$ & 2.65 & 2.56 & 2.69 & 2.66 \\
\hline \multicolumn{6}{|c|}{ Cronbach's alpha $=0.849$ (internally consistent) } \\
\hline
\end{tabular}

Moreover, best practice suggests that if the adopted standard form of contract document does not make adequate references to manage $H \& S$, then project specific conditions of contract which clearly outline H\&S specifications is required. Although evidence points to inadequate $H \& S$ provisions in the standard forms of contract, it is evident from the results that public clients do not usually develop project specific conditions of contract to manage project H\&S risks. For instance, Sharkey et al. [59] exemplified this best practice when they found that up to $78 \%$ of the time, Australian construction clients specified additional $H \& S$ clauses to the standard forms of contract to adequately deal with H\&S issues on their projects.

Clearly, due to the inadequate H\&S specifications in the conditions of contract, it is believed that the contract conditions generally do not prescribe penalties or ramifications for poor H\&S performance and/or incentive packages for delivering accident-free projects. Therefore, if a contractor fails to provide adequately safe systems of work, which may result in accidents or work-related diseases, the client may not have the contractual basis to demand corrective/remedial actions or penalise the contractor for such a failure. That notwithstanding, contract conditions which lack H\&S clauses do not absolve contractors from safeguarding the $\mathrm{H} \& \mathrm{~S}$ of their workers and the public. Certainly, the contractor is mandated to abide by the existing H\&S legislation. However, addressing H\&S issues in conditions of contract in an adequate manner delivers a clear message on the importance of H\&S within the project. Finally, although it is acknowledged that contract negotiations provide an avenue to emphasise the need for a comprehensive $H \& S$ programme and reach a clear agreement with the contractor to maintain specific $H \& S$ conditions and policies [60], the respondents believe that $\mathrm{H} \& \mathrm{~S}$ issues are seldom discussed in contract negotiations for public projects.

\subsubsection{ANOVA Test of the Conditions of Contract Items}

An ANOVA test has been conducted to determine any significant differences in the responses among the various organisations and the results presented in Table 12. Following fulfilment of the assumptions of normality and homogeneity of variances of the data, the regular one-way ANOVA was performed. From the table, it is evident that the views of respondents from the different organisations on the H\&S considerations in conditions of contract did not differ significantly from each other. Thus, in essence, the respondents views have not been influenced by the nature of their organisations. 
Table 12. One-way ANOVA for H\&S considerations in conditions of contract.

\begin{tabular}{ccccccc}
\hline & \multicolumn{2}{c}{ Test for Normality } & \multicolumn{2}{c}{ Homogeneity test } & \multicolumn{2}{c}{ ANOVA } \\
\hline S/n & Kurtosis & Skewness & Levene & Sig. & F & Sig. \\
\hline COC1 & -0.841 & 0.162 & 0.352 & 0.704 & 1.992 & 0.096 \\
COC2 & -0.862 & 0.322 & 0.402 & 0.669 & 1.290 & 0.274 \\
COC3 & -0.785 & 0.497 & 0.184 & 0.832 & 0.283 & 0.889 \\
COC4 & -0.753 & 0.417 & 1.488 & 0.228 & 1.272 & 0.281 \\
\hline
\end{tabular}

\subsubsection{Relationships Between the Conditions of Contract Items}

Table 13 presents the relationship between the conditions of contract items. The results demonstrate strong relationships among the items. The correlation matrix indicates that if a client adopts a standard form of contract that has generic clauses relating to H\&S, the client may likely develop additional or specific conditions of contract which would clearly specify the H\&S standards required for the project, as well as the contractors H\&S responsibilities. Specific conditions of contract allow for additional clauses on H\&S and they ensure that all H\&S responsibilities of contractors, subcontractors and all those involved in the project are clearly defined and made contractually binding [61]. While the conditions of contract may specify the $\mathrm{H} \& \mathrm{~S}$ obligations of contractors and other project participants throughout the project, the correlation reveals that such conditions may likely prescribe penalties for breaching the H\&S provisions and/or provide bonuses for adequate fulfilment of the provisions. Furthermore, the relationship has revealed that considering $\mathrm{H} \& \mathrm{~S}$ issues in contract negotiations provides an important tool for developing project specific $\mathrm{H} \& \mathrm{~S}$ conditions of contract and enables consequences for poor $\mathrm{H} \& \mathrm{~S}$ performance to be prescribed.

Table 13. Correlation coefficient between the H\&S considerations in conditions of contract.

\begin{tabular}{cccccc}
\hline Spearman's Rho & Experience & COC1 & COC2 & COC3 & COC4 \\
\hline Experience & 1 & & & & \\
COC1 & $-0.288^{* *}$ & 1 & & & \\
COC2 & $-0.332^{* *}$ & $0.612^{* *}$ & 1 & & \\
COC3 & $-0.406^{* *}$ & $0.513^{* *}$ & $0.643^{* *}$ & 1 & \\
COC4 & $-0.291^{* *}$ & $0.433^{* *}$ & $0.635^{* *}$ & $0.589^{* *}$ & 1 \\
\hline
\end{tabular}

** Correlation is significant at the 0.01 level (two-tailed).

\subsubsection{Contract Administration and Monitoring Stage}

Contract administration and monitoring are purposely aimed at ensuring that contractors and all other project participants abide by the conditions of contract and execute the project in accordance with the requirements and specifications. In terms of $\mathrm{H} \& S$, the contractors' and subcontractors' H\&S performances are monitored to ensure that their $\mathrm{H} \& S$ obligations are delivered in accordance with regulatory and contractual requirements. Therefore, monitoring H\&S performance is essential to the effective management of H\&S.

The views of respondents in relation to the $\mathrm{H} \& \mathrm{~S}$ considerations in contract administration and monitoring are presented in Table 14. The results indicate that public clients or their representatives do not adequately monitor their contractors' H\&S performance during the construction stage. This provides evidence for, and emphasises, the argument that H\&S issues are not a priority for clients when managing and monitoring contractors throughout the duration of the project [3,29]. Moreover, since there is a lack of adequate consideration of H\&S issues in the earlier procurement stages, it is understandable that $\mathrm{H} \& \mathrm{~S}$ is also not considered adequately in contract administration and monitoring. 
Table 14. H\&S considerations in contract administration and monitoring.

\begin{tabular}{|c|c|c|c|c|c|}
\hline $\mathrm{S} / \mathbf{n}$ & Consideration & Consultants & Contractors & Gov't Inst. & Overall \\
\hline MON1 & $\begin{array}{l}\text { Public clients usually collect periodic reports on H\&S during } \\
\text { the construction phase of their projects in order to track H\&S } \\
\text { performance. }\end{array}$ & 2.66 & 2.62 & 2.58 & 2.64 \\
\hline MON2 & $\begin{array}{l}\text { Predetermined H\&S targets are usually used to monitor, and } \\
\text { track H\&S performance of contractors on public projects for } \\
\text { the entire duration of the contract. }\end{array}$ & 2.68 & 2.57 & 2.58 & 2.62 \\
\hline MON3 & $\begin{array}{l}\text { Public clients usually take the necessary actions to improve } \\
\text { H\&S implementation on their project immediately when their } \\
\text { attention is drawn to unsafe acts. }\end{array}$ & 3.13 & 3.01 & 3.08 & 3.08 \\
\hline MON4 & $\begin{array}{l}\text { Public clients always require main contractors on their } \\
\text { projects to nominate subcontractors that are } H \& S \text { competent. }\end{array}$ & 2.74 & 2.82 & 2.81 & 2.80 \\
\hline
\end{tabular}

Effective monitoring of $H \& S$ performance allows clients to provide feedback to contractors and demands corrective/remedial actions where necessary. This requires a systematic approach to collecting and keeping records in order to track H\&S performance against the set H\&S targets. While these records may attest to the client's due diligence on the contractors' H\&S implementation, they also provide crucial documentary evidence in circumstances where there is a breach of $\mathrm{H} \& \mathrm{~S}$ requirements or an occurrence of an accident or incident resulting from contractor's activities. Thus, monitoring the contractor's compliance with the $H \& S$ requirement in the contract is an important responsibility of clients, yet it is believed that this important exercise is barely undertaken by public clients in Ghana.

Moreover, the results show that the majority of public clients do not take the needed action to improve H\&S performance on their project, even when their attention is drawn to potentially risky activities of contractors. It is also revealed that clients do not necessarily require contractors to appoint subcontractors who are H\&S competent to be on their projects. These may be a result of the lack of explicit contractual provisions which specify the contractor's H\&S obligations and the level of client's monitoring and involvement throughout the construction stage. Subcontracting has been highlighted as one of the main challenges to the implementation of H\&S issues on construction sites [62,63]. Therefore, public clients' lack of interest in how subcontractors are appointed by contractors may have dire consequences for the management of $H \& S$ on their projects.

\subsubsection{ANOVA Test of the Contract Administration and Monitoring Items}

The ANOVA test resulting from the responses of consultants, contractors and government institutions has been performed and the results are presented in Table 15. As usual, the assumptions of normality and homogeneity of variances were determined to have been fulfilled before the regular one-way ANOVA was performed. The results show that there were no significant differences in terms of the mean responses from the different organisations. This demonstrates that the responses have not been influenced by the nature of the respondents' organisations.

Table 15. One-way ANOVA on H\&S considerations in contract administration and monitoring.

\begin{tabular}{ccccccc}
\hline & \multicolumn{2}{c}{ Test for Normality } & \multicolumn{2}{c}{ Homogeneity test } & \multicolumn{2}{c}{ ANOVA } \\
\hline S/n & Kurtosis & Skewness & Levene & Sig. & F & Sig. \\
\hline MON1 & -0.600 & 0.619 & 0.096 & 0.908 & 1.211 & 0.306 \\
MON2 & -0.661 & 0.495 & 0.246 & 0.782 & 0.546 & 0.702 \\
MON3 & -0.966 & -0.269 & 1.763 & 0.174 & 0.217 & 0.929 \\
MON4 & -0.610 & 0.140 & 0.209 & 0.811 & 0.316 & 0.867 \\
\hline
\end{tabular}




\subsubsection{Relationships between the Contract Administration and Monitoring Items}

The relationship between the H\&S items in contract administration and monitoring have been analysed using Spearman's correlation and the results are presented in Table 16. The correlation analysis found significant positive relationships among the H\&S items in contract administration and monitoring. The relationship demonstrates that a systematic approach to collecting and keeping H\&S records on projects is likely to aid clients in tracking H\&S performance against the set objectives/targets in relation to H\&S. It is acknowledged that one way by which clients could fulfil their obligations towards H\&S is by monitoring the contractor's compliance with the regulatory and contractual requirements relating to H\&S $[27,38]$. Effective monitoring of the contractor's H\&S performance allows clients to detect problems early, thereby avoiding accidents or illnesses. By collecting and reviewing the contractor's H\&S performance records, clients can proactively monitor and track H\&S performance against targets and take the necessary measures or demand corrective actions where contractual or regulatory breaches are identified. Thus, it is important to collect and review $\mathrm{H} \& \mathrm{~S}$ records throughout the project in order to pursue contractual, regulatory and other remedies to enforce $\mathrm{H} \& \mathrm{~S}$ issues on projects.

Table 16. Correlation coefficient between the H\&S considerations in contract administration and monitoring.

\begin{tabular}{cccccc}
\hline Spearman's Rho & Experience & MON1 & MON2 & MON3 & MON4 \\
\hline Experience & 1 & & & & \\
MON1 & $-0.348^{* *}$ & 1 & & & \\
MON2 & $-0.285^{* *}$ & $0.734^{* *}$ & 1 & & \\
MON3 & $-0.017^{* *}$ & $0.429^{* *}$ & $0.471^{* *}$ & 1 & \\
MON4 & $-0.200^{* *}$ & $0.446^{* *}$ & $0.533^{* *}$ & $0.604^{* *}$ & 1 \\
\hline
\end{tabular}

** Correlation is significant at the 0.01 level (two-tailed).

Further, clients who take the needed actions to improve H\&S implementation on their projects when prompted about any unsafe acts are likely to demand that main contractors on their projects appoint only H\&S competent subcontractors. Subcontracting has been recognised to be associated with unsafe and illegal work practices partly due to factors such as the urgent economic priorities of subcontractors and the disorganisation of construction sites because of subcontracting [62]. Thus, subcontracting comes along with additional risk factors and the evidence of the resulting unsafe practices may come to the attention of the client. In such situations, clients who take appropriate actions to improve the H\&S implementation will likely demand that the contractor must subsequently appoint only $\mathrm{H} \& \mathrm{~S}$ conscious subcontractors.

\subsubsection{H\&S Performance on Public Projects}

Table 17 presents the general view of the respondents regarding H\&S performance on public projects in Ghana. The results show that generally, H\&S performance on public projects is not good. This result may not be a surprise considering that the poor H\&S performance of the construction industry in developing countries is well documented $[1,64-66]$. This result demonstrates that project participants, particularly the client, contractors, subcontractors, and government regulators, do not take the appropriate actions to effectively prevent incidents and accidents, which can result in fatalities, injuries, and diseases of employees and the public.

Table 17. H\&S performance of public projects.

\begin{tabular}{cccccc}
\hline S/n & Consideration & Consultants & Contractors & Gov't Inst. & Overall \\
\hline PER1 & $\begin{array}{c}\text { H\&S performance on public } \\
\text { projects has mostly been very good. }\end{array}$ & 2.48 & 2.47 & 2.55 & 2.52 \\
\hline
\end{tabular}




\section{Conclusions and Recommendations}

This study has provided an evidence-based assessment of the extent to which construction H\&S issues are considered in the procurement of public sector projects in Ghana. This is based on the premise that decisions and choices made within the various stages of procurement have direct and indirect influence on the management of $H \& S$ in projects. Moreover, as the major procurers of construction projects, public sector clients can use their enormous purchasing power to influence the behaviour of the construction industry by adequately considering $H \& S$ issues in their procurement decisions.

Through a quantitative research approach, the study found that H\&S issues are given low priority and as a result, not given adequate consideration in public procurement in Ghana. The findings suggest that public clients do not set clear project objectives relating to $\mathrm{H} \& \mathrm{~S}$ and do not adequately consider $\mathrm{H} \& \mathrm{~S}$ issues in the various stages of the procurement process, including planning, tendering, tender evaluation and contract award, conditions of contract, and contract administration and monitoring. Consequently, this limitation reflects the poor H\&S performance in public sector projects. Through ANOVA, it became clear that this belief is shared by all the construction industry professionals, irrespective of the nature of their organisations. The relationships that exist between the various procurement stage activities suggest that an adequate consideration of H\&S issues in one activity could trigger further H\&S considerations in others. The findings call attention to the need for the establishment of a nationally consistent approach to promoting H\&S through public procurement. Following the example of Australia, the government of Ghana can develop policies and guidance documents relating to $\mathrm{H} \& \mathrm{~S}$ in public procurement to be applied in all public sector projects. Alternatively, the Public procurement Act of 2003 (Act 663) and the Public Procurement (Amendment) Act of 2016 (Act 914) may be amended to adequately consider H\&S issues throughout the procurement process.

This study adds to the broader research on H\&S improvement in developing countries by assessing the extent of $\mathrm{H} \& \mathrm{~S}$ considerations in the procurement of public projects in Ghana. Understanding the extent of H\&S consideration in public procurement in the current setting is an important first step to advocating for better procurement practices that promote H\&S. Public clients must show the needed leadership and integrate H\&S issues into their procurement decision-making. This is because contractors who work on public projects also discharge H\&S duties on behalf of the public sector client. The leadership and involvement of public sector clients do not only promote $H \& S$ issues on their projects but also, they set a trend for all stakeholders to follow, thereby improving the $H \& S$ performance of the construction industry in Ghana.

Despite the contribution of this research, there are a few limitations that must be acknowledged. Firstly, the findings of this research are based primarily on the perspective of construction industry professionals in Ghana. The viewpoint of construction industry professionals in other developing countries may be different depending on the norms and practices in those countries. However, considering that the construction industries in developing countries share similar characteristics [67], the findings in this research may be applicable to many other developing countries. Another limitation of this research is the use of a single approach to data collection. While the evidence is enough to draw conclusions, future efforts may focus on a mixed method which offers the possibility for methodological triangulation.

Author Contributions: E.F.B. is the lead author, completing most of the writing of this paper. R.Y.S. and C.C.W. suggested many revisions that were incorporated in the paper. All authors have read and agreed to the published version of the manuscript.

Funding: This research received no external funding.

Institutional Review Board Statement: The method used in this study was approved by the Human Research Ethics Committee of UNSW Built Environment (HC190652, Date: 12/09/2019). 
Informed Consent Statement: Informed consent was obtained from all participants involved in the study.

Data Availability Statement: Data are available from the authors upon request.

Conflicts of Interest: The authors declare no conflict of interest.

\section{References}

1. Murie, F. Building safety-An international perspective. Int. J. Occup. Environ. Health 2007, 13, 5-11. [CrossRef]

2. Commission of the European Communities. Safety and Health in the Construction Sector; Office for Official Publications of the European Communities: Luxembourg, 1993.

3. Hislop, R. Construction Site Safety: A Guide for Managing Contractors; Lewis Publishers: Boca Raton, FL, USA, 1999.

4. Votano, S.; Sunindijo, R.Y. Client safety roles in small and medium construction projects in Australia. J. Constr. Eng. Manag. 2014, 140, 04014045. [CrossRef]

5. Huang, X.; Hinze, J. Owner's role in construction safety. J. Const. Eng. Manag. 2006, 2, 164-173. [CrossRef]

6. Lingard, H.; Blismas, N.; Cooke, T.; Cooper, H. The model client framework: Resources to help Australian government agencies to promote safe construction. Int. J. Manage. Projects Bus. 2009, 2, 131-140. [CrossRef]

7. The American Society of Civil Engineers. Policy Statement 350—Construction Site Safety; ASCE: Reston, VA, USA, 2012.

8. Health and Safety Commission. Managing Health and Safety in Construction. Construction (Design and Management) Regulations Approved Code of Practice; Health and Safety Commission: Norwich, UK, 2007.

9. Gibb, A.G.; Lingard, H.; Behm, M.; Cooke, T. Construction accident causality: Learning from different countries and differing consequences. Constr. Manag. Econ. 2014, 32, 446-459. [CrossRef]

10. Lingard, H.; Oswald, D.; Le, T. Embedding occupational health and safety in the procurement and management of infra-structure projects: Institutional logics at play in the context of new public management. Const. Manag. Econ. 2019, 37, 567-583. [CrossRef]

11. Lingard, H.; Wakefield, R.; Walker, D. The client's role in promoting work health and safety in construction projects: Balancing contracts and relationships to effect change. Constr. Manag. Econ. 2020, 38, 1-16. [CrossRef]

12. Ju, C.; Rowlinson, S. The evolution of safety legislation in Hong Kong: Actors, structures and institutions. Saf. Sci. 2020, 124, 104606. [CrossRef]

13. Public Procurement Authority (PPA). Building a resilient private sector. The Procurement Digest. PPA. Accra. 2013. Available online: https:/ / capturetribe.com/theppa/wp-content/uploads/2019/01/Procurement-Digest-2013-online.pdf (accessed on 1 March 2021).

14. Health and Safety Authority. Clients in Construction Best Practice Guidance; Health and Safety Authority: Dublin, UK, 2009.

15. Rwelamila, P.D.; Smallwood, J.J. Appropriate project procurement systems for hybrid TQM. In Proceedings of the CIB W99 International Conference Implementation of Safety and Safety on Construction Sites, Honolulu, Hawaii, 24-27 March 1999; Singh, A., Hinze, J.W., Coble, R.J., Eds.; A. A. Balkema Publishers: Rotterdam, The Netherlands, 1999; pp. 87-94.

16. Health and Safety Executive. Health and Safety in Public Sector Construction Procurement, A Follow-Up Study; Health and Safety Executive: London, UK, 2011.

17. Amann, M.; Roehrich, J.K.; Eßig, M.; Harland, C. Driving sustainable supply chain management in the public sector: The importance of public procurement in the European Union. Supply Chain Manag. 2014, 19, 351-366. [CrossRef]

18. Mahmood, S.A.I. Public procurement and corruption in Bangladesh. confronting the challenges and opportunities. J. Public Adm. Pol. Res. 2010, 2, 103-111.

19. European Commission. Public Procurement Indicators 2015; European Commission: Brussels, Belgium, 2016. Available online: https:/ / ec.europa.eu/docsroom/documents/20679/attachments/1/translations/en/renditions/pdf (accessed on 16 March 2019).

20. Organisation for Economic Co-operation and Development (OECD). Government at a Glance; OECD: Paris, France, 2013. Available online: http:/ / www.oecd-ilibrary.org/governance/government-at-a-glance-2013/general-government-procurement-as-shareof-total-general-government-expenditures-2011_gov_glance-2013-graph99-en (accessed on 1 April 2019).

21. Organisation for Economic Co-operation and Development (OECD). Size of public procurement. In Government at a Glance 2017; OECD Publishing: Paris, France, 2017.

22. The World Bank. Ghana's Comprehensive Approach to Public Procurement Reform; The World Bank: Geneva, Switzerland, 2013.

23. McCrudden, C. Using public procurement to achieve social outcomes. Nat. Resour. Forum 2004, 28, 257-267. [CrossRef]

24. Watermeyer, R.B. The use of procurement to attain labour-based and poverty alleviation objectives. In Proceedings of the 9th Regional Seminar for Labour-Based Practitioners: Towards Appropriate Engineering Practices and an Enabling Environment, Maputo, Mozambique, 20-24 May 2002; Mason, D.J., Ed.; National Road Administration (ANE): Maputo, Mozambique, 2002.

25. Brammer, S.; Walker, H. Sustainable procurement in the public sector: An international comparative study. Int. J. Oper. Prod. Manag. 2011, 31, 452-476. [CrossRef]

26. Construction Industry Development Board (CIDB). Delivery Management Guidelines: Practice Guide 2-Construction Procurement Strategy; CIDB: Pretoria, South Africa, 2011.

27. Wells, J.; Hawkins, J. Briefing: Promoting construction health and safety through procurement. Proc. Inst. Civ. Eng. Manag. Procure. Law 2011, 164, 165-168. [CrossRef] 
28. Benviolent, C.; Smallwood, J. Assessing the implications of public sector procurement on construction health and safety management in Zimbabwe. In Proceedings of the 9th CIDB Conference. Emerging Trends in Construction Organisational Practices and Project Management Knowledge Areas, Cape Town, South Africa, 2-4 February 2016; Windapo, A.O., Odediran, S.J., Adediran, A., Eds.; Department of Construction Economics and Management, University of Cape Town: Cape Town, South Africa, 2016

29. Donkoh, D.; Adinyirah, E.; Aboagye-Nimo, E. An exploratory study into promoting construction health and safety in Ghana through public works procurement. In Benefitting Workers and Society through Inherently Safe( $r$ ) Construction; Behm, M., McAleenan, C., Eds.; CIB: Belfast, UK, 2015; pp. 289-297.

30. Creswell, J.W. Research Design: Qualitative, Quantitative, and Mixed Methods Approaches; Sage: Los Angeles, CA, USA, 2009.

31. Root, D.; Blismas, N.G. Increasing questionnaire responses from industry: Practices surrounding the use of postal questionnaires. In Proceedings of the 19th Annual ARCOM Conference, Brighton, UK, 3-5 September 2003; Greenwood, D.J., Ed.; Association of Researchers in Construction Management: Reading, UK, 2003; Volume 2, pp. 623-631.

32. Keeter, S.; Kennedy, C.; Dimock, M.; Best, J.; Craighill, P. Gauging the Impact of Growing Nonresponse on Estimates from a National RDD Telephone Survey. Public Opin. Q. 2006, 70, 759-779. [CrossRef]

33. Akintoye, A.; Main, J. Innovation through Collaborative Procurement Strategy and Practices; John Wiley and Sons: Hoboken, NJ, USA, 2012; pp. 251-276.

34. International Organization for Standardization (ISO). ISO 10845-1:2010: Construction Procurement-Part 1: Processes, Methods and Procedures; ISO: Geneva, Switzerland, 2010.

35. McCue, C.; Gianakis, G. Public purchasing: Who's minding the store? J. Public Procure. 2001, 1, 71-95. [CrossRef]

36. Kassel, D.S. Performance, accountability, and the debate over rules. Public Adm. Rev. 2008, 68, 241-252. [CrossRef]

37. Basheka, B.C. Procurement planning and local governance in Uganda: A factor analysis approach. Int. J. Procure. Manag. 2009, 2, 191. [CrossRef]

38. Worksafe Victoria. A Handbook for the Public Sector. Health and safety in Construction Procurement, 2nd ed.; Worksafe Victoria: Geelong, Australia, 2017.

39. Hair, J.F.; Black, W.C.; Babin, B.J.; Anderson, R.E. Multivariate Data Analysis, 7th ed.; Prentice Hall: Upper Saddle River, NJ, USA, 2009.

40. Hinton, P.; McMurray, I.; Brownlow, C. SPSS Explained; Routledge Taylor \& Francis Group: London, UK, $2004 ;$ pp. 363-364.

41. Likert, R. A technique for the measurement of attitudes. Arch. Psychol. 1932, 22, 55.

42. Alkilani, S.Z.; Jupp, J.; Sawhney, A. Issues of construction health and safety in developing countries: A case of Jordan. Australas. Constr. Econ. Build. 2013, 13, 141-156. [CrossRef]

43. Lingard, H.; Rowlinson, S. Occupational Health and Safety in Construction Project Management; Spon Press: London, UK, 2005.

44. Mortledge, R.; Smith, A.; Kashiwagi, D.T. Building Procurement; Blackwell: Oxford, UK, 2006.

45. Byrne, B.M. Structural Equation Modeling with AMOS: Basic Concepts, Applications, and Programming, 3rd ed.; Routledge: New York, NY, USA, 2016; pp. 94-98.

46. Han, Y.; Feng, Z.; Zhang, J.; Jin, R.; Aboagye-Nimo, E. Employees' safety perceptions of site hazard and accident scenes. J. Constr. Eng. Manag. 2019, 145, 04018117. [CrossRef]

47. Safe Work Australia. Work Health and Safety Perceptions: Construction Industry; Safe Work Australia: Canberra, Australia, 2015.

48. Office of the Federal Safety Commissioner (OFSC). The Model Client Framework: The Model Client: Promoting Safe Construction; Office of the Federal Safety Commissioner: Canberra, Australia, 2008.

49. Roughton, J.E.; Mercurio, J.J. Developing an Effective Safety Culture: A Leadership Approach; Butterworth-Heinemann: Oxford, UK, 2002.

50. Lingard, H.; Piezadeh, P.; Harley, J.; Blismas, N.; Wakefield, R. Safety in Design; RMIT: Melbourne, Australia, 2014.

51. Trethewy, R.; Gardner, D. OHS Performance: Improved indicators for contractors. J. Occup. Health Saf. Australia N. Z. 2000, 16, 527-534.

52. Cooperative Research Centre for Construction Innovation (CRC). Capital Works Procurement: The Selection of a Building Procurement Method; CRC for Construction Innovation: Brisbane, Australia, 2009.

53. Smallwood, J.J. The role of project managers in occupational health and safety. In Proceedings of the First International Conference of CIB Working Commission W99 Implementation of Safety and Health on Construc-tion Sites, Lisbon, Portugal, 4-7 September 1996; Dias, L.A., Coble, R.J., Eds.; Balkema: Rotterdam, The Netherlands, 1996; pp. 227-236.

54. Harding, T. Procurement and health and safety: Has health and safety been forgotten in all the bureaucracy. In Proceedings of the Public Services Group and Yorkshire Branch Joint Networking Event, IOSH, Pontefract, UK, 29 January 2014.

55. Okorie, V.; Emuze, F.; Smallwood, J.; Van Wyk, J. The influence of clients' leadership in relation to construction health and safety in South Africa. Acta Structilia 2014, 21, 44-68.

56. Ameyaw, E.E.; Pärn, E.; Chan, A.P.; Owusu-Manu, D.; Edwards, D.J.; Darko, A. Corrupt practices in the construction industry: Survey of ghanaian experience. J. Manag. Eng. 2017, 33, 05017006. [CrossRef]

57. Osei-Tutu, E.; Badu, E.; Owusu-Manu, D. Exploring corruption practices in public procurement of infrastructural projects in Ghana. Int. J. Manag. Proj. Bus. 2010, 3, 236-256. [CrossRef]

58. The World Bank. Procurement Guidance-Evaluation Criteria, Use of Evaluation Criteria for Procurement of Goods, Works, and Non-Consulting Services Using RFB and RFP; The World Bank: Washington, DC, USA, 2016. 
59. Sharkey, J.A.M.; Bell, M.; Jocic, W.; Marginean, R. Standard Forms of Contract in the Australian Construction Industry: Research Report; The University of Melbourne: Melbourne, Australia, 2014.

60. New York Committee for Occupational Safety and Health (NYCOSH). Bargaining to promote safety and health, NYCOSH 2014. Available online: http:/ / nycosh.org/wpcontent/uploads/2014/10/Bargaining-to-Promote-Safety-and-Health-NYCOSH.pdf (accessed on 21 August 2020).

61. Australian Safety and Compensation Council (ASCC). Guidance on Occupational Health and Safety in Government Procurement; ASCC: Canberra, Australia, 2006.

62. Mayhew, C.; Quinlan, M. Subcontracting and occupational health and safety in the residential building industry. Ind. Relat. J. 1997, 28, 192-205. [CrossRef]

63. Manu, P.; Ankrah, N.; Proverbs, D.; Suresh, S. Mitigating the health and safety influence of subcontracting in construction: The approach of main contractors. Int. J. Proj. Manag. 2013, 31, 1017-1026. [CrossRef]

64. Eyiah, A.K.; Kheni, N.A.; Quartey, P.D. An Assessment of occupational health and safety regulations in Ghana: A study of the construction industry. J. Build. Constr. Plan. Res. 2019, 7, 11-31. [CrossRef]

65. Hämäläinen, P.; Takala, J.; Kiat, T.B. Global Estimates of Occupational Accidents and Work-Related Illnesses 2017; Workplace Safety and Health Institute, Ministry of Manpower Services Centre: Singapore, 2017.

66. Gibb, A.G.F.; Bust, P. Construction Health and Safety in Developing Countries; European Construction Institute: Loughborough, UK, 2006.

67. Boadu, E.F.; Wang, C.C.; Sunindijo, R.Y. Characteristics of the construction industry in developing countries and its implications for health and safety: An exploratory study in Ghana. Int. J. Environ. Res. Public Health 2020, 17, 4110. [CrossRef] [PubMed] 